\title{
The Cardioprotective Properties of Agaricomycetes Mushrooms Growing in the territory of Armenia (Review)
}

\author{
Susanna M. Badalyan ${ }^{1}$, Anush Barkhudaryan², Sylvie Rapior ${ }^{3}$
}

${ }^{1}$ Laboratory of Fungal Biology and Biotechnology, Institute of Pharmacy, Department of Biomedicine, Yerevan State University, Yerevan, Armenia; ${ }^{2}$ Department of Cardiology, Clinic of General and Invasive Cardiology, University Hospital № 1, Yerevan State Medical University, Yerevan, Armenia; ${ }^{3}$ Laboratoire de Botanique, Phytochimie et Mycologie, Faculté de Pharmacie, CEFE, Univ Montpellier, CNRS, EPHE, IRD, Montpellier, France

*Address for correspondence: Susanna M. Badalyan, Laboratory of Fungal Biology and Biotechnology, Institute of Pharmacy, Yerevan State University, 1 A. Manoogian St., 0025 Yerevan, Armenia; E-mail: s.badalyan@ysu.am

\section{Short title: Cardioprotective mushrooms of Armenia}

Keywords: Agaricomycetes, anti-hypertensive, anti-obesity, anti-oxidative, anti-inflammatory, Armenia, cardioprotective, hypoglycemic, hypocholesterolemic, fibrinolytic, medicinal mushrooms

ABBREVIATIONS: AAS: anti-atherosclerotic; ACE: angiotensin-converting enzyme; AH: arterial hypertension; AIE: anti-inflammatory; AOA: antioxidant activity; CL: cultural liquid; CPE: cardioprotective effect; CVD: cardiovascular disease; DCM: diabetic cardiomyopathy; FLA: fibrinolytic activity; HCE: hypocholesterolemic effect; HDL: high-density lipoproteins; HGE: hypoglycemic effect; HMG-CoA: 3-hydroxyl-3-methylglutaryl Coenzyme A; HTE: hypotensive effect; LDL: low-density lipoprotein; LVEF: left ventricular ejection fraction; ME: mycelial extract; MM: medicinal mushrooms; MS: metabolic syndrome; NLRP3: NOD-like receptor protein 3; NOD: nucleotide-binding oligomerization domain; RAS: renin-angiotensin system; TGF-p1: transforming growth factor $\beta-1$; TLA: thrombolytic activity.

ABSTRACT: Several edible and medicinal Agaricomycetes mushrooms possess biologically active compounds with different therapeutic effects, such as anti-oxidative, anti-inflammatory, hypocholesterolemic, hypoglycemic, anti-hypertensive, fibrinolytic, thrombolytic, potentially used as cardioprotective remedies. Previous studies have shown that mushrooms possessing cardioprotective effect (CPE) contain a high amount of vitamins and minerals, low contents of fat which makes them applicable as supplementary dietary and functional food for prevention and treatment of a variety of cardiovascular disease (CVD). The current review is directed to the evaluation of resource value of 31 edible and non-edible medicinal Agaricomycetes mushrooms with potential CPE growing in the 
territory of Armenia and discusses the future perspectives of their usage in biotechnology and biomedicine.

\section{INTRODUCTION}

Cardiovascular disease (CVD) affects the heart and circulatory system and is considered the leading cause of mortality worldwide. The main risk factors for CVD include metabolic syndrome (MS), arterial hypertension (AH), high levels of blood glucose and cholesterol. Several pathological conditions, including diabetes, obesity, drug toxicity, aging, and oxidative stress, have a significant role in the development of CVD. Among the variety of CVD, AH affects $15-20 \%$ of all adults which may be complicated by atherosclerosis, stroke and myocardial infarction. The renin-angiotensin system (RAS) plays an important role in the pathophysiology of AH. ${ }^{1}$ The activation of RAS leads to an increased production of angiotensin II from angiotensin I, facilitated by the angiotensinconverting enzyme (ACE), which is associated with the development of AH and myocardial remodeling. The atherosclerosis is considered a major risk factor for CVD, in particular coronary artery disease, characterized by accumulation of lipoproteins and fibrous elements in the vessel wall. Inflammation and oxidative stress are associated with atherosclerosis and play a major role in the development of CVD. Furthermore, the development of thrombosis in the coronary artery can lead to myocardial infarction due to fibrin aggregation in the blood. ${ }^{2}$ The thromboembolic complications may develop as a result of deep vein thrombosis, surgery, certain medications and hypodynamic lifestyle. The thrombus blocks the blood flow depriving tissues of normal blood supply and oxygen. The processes of thrombus formation and fibrinolysis (fibrin dissolution by proteolytic enzymes) are balanced in biological systems. Thus, hyperglycemia, hyperlipidemia, insulin resistance, obesity, atherosclerosis, $\mathrm{AH}$ and thrombosis are associated with MS and are considered risk biomarkers contributing to the development of CVD.

The existing drugs, such as insulin, inhibitors of 3-hydroxyl-3-methylglutaryl Coenzyme A (HMG$\mathrm{CoA}$ ) reductase, aldose reductase, ACE, and $\alpha$-glucosidase, used for the treatment of MS, possess limited therapeutic efficacy and several side effects. Currently, the main areas of biomedical research are directed to the prevention and treatment of CVD, and considerable effort has been made in the pharmacological industry to develop new preparations with natural origin to improve glucose and lipid metabolism without significant side effects.

Mushrooms are considered natural sources of different groups of bioactive compounds (phenolics, terpenoids, polysaccharides, oligopeptides, sterols, etc.) and enzymes (proteases) possessing hypocholesterolemic, hypoglycemic, hypotensive, anti-inflammatory, antioxidative, as well as fibrino- and thrombolytic effects. ${ }^{3-26}$ Furthermore, mushrooms also possess a high content of proteins, 
unsaturated fatty acids, fiber, vitamins (B complex, C, D, E, H, K, PP), minerals (Fe, K, Mn, Na, Se, $\mathrm{Zn}$ ) and a low concentration of sodium. ${ }^{27-30}$ The pharmacological and nutritional properties of mushrooms allow considering them as functional food for the prevention and treatment of various diseases, including CVD. ${ }^{31-36}$ Previous studies suggest that regular consumption of edible mushrooms may potentially reduce the risk of CVD. ${ }^{37-42}$ The focus of the current review is to assess the resource value of edible and non-edible Agaricomycetes medicinal mushrooms (MM) with potential CPE growing in the territory of Armenia and evaluate the perspectives for their usage in biotechnology and biomedicine.

\section{THE CARDIOPROTECTIVE EFFECT OF MUSHROOMS}

Mushrooms have been prescribed in traditional medicine due to their diverse bioactivity to reduce the risk of CVD (Table 1). The reported therapeutic properties of MM (e.g. anti-oxidative, antiinflammatory, anti-atherosclerotic, anti-hypertensive, anti-obesity, hypoglycemic, hypolipidemic and fibrinolytic) may be clinically relevant in the prevention and treatment of cardiac diseases. $3,4,11,14,15,37$ 43

The maintenance of balance between free radical production and antioxidant defence is an essential condition for normal functioning of biological organisms. Free radicals may damage cellular lipids, proteins, and DNA, affect their normal function and lead to the development of various diseases. The natural products with antioxidant activity (AOA) are considered potential protective agents against oxidative damage. The development of CVD may also be prevented by the dietary intake of natural antioxidants, including mushrooms. They neutralize free radical elements by enhancing the activity of catalase and superoxide dismutase, and stabilize glutathione and malondialdehyde levels. ${ }^{12}$ In this regard, Agaricus brasiliensis, Agrocybe aegerita, Boletus edulis, Flammulina velutipes, Hericium erinaceus, Lentinula edodes, Trametes versicolor, Volvariella volvacea as well as mushrooms species from genera Pleurotus and Ganoderma are considered a natural source of biomolecules (fatty acids, phenolics, polysaccharides, steroids, terpenoids, tocopherols, etc.) with anti-atherosclerotic (AAS), anti-inflammatory (AIE), antioxidant, anti-hypertension, cardioprotective, hypocholesterolemic (HCE), hypoglycemic (HGE) and hypotensive (HTE) effects. . $^{3,411-16,27,30,35,39,40}$ The lanostane type triterpenoids isolated from Ganoderma lucidum were suggested as promising bioactive agents for the treatment of MS. ${ }^{6}$ In vitro study and animal assays, as well as several human trials suggest that Agaricus bisporus G. lucidum, H. erinaceus, Phellinus linteus and Pleurotus species may normalize blood glucose and lipid levels. ${ }^{416-18,20,21}$ The eritadenine extracted from L. edodes has been identified as an anti-atherogenic compound which not only improves lipid metabolism but also inhibits in vitro activity of ACE. ${ }^{10}$ In vitro anti-atherogenic, ACE and HMG-CoA reductase inhibitory effects, as well 
as the protection of endothelium against oxidative stress were evaluated in Pleurotus pulmonarius. ${ }^{20}$ Several edible MM due to a high content of unsaturated fatty acids possess AAS effect, and their consumption may have a beneficial effect on the cellular metabolism in the human body. ${ }^{29,30}$ Although the mechanisms of hypocholesterolemic and hypoglycemic effects of mushroom-derived metabolites are unclear, several species, such as A. bisporus, Auricularia polytricha, F. velutipes, G. lucidum, Grifola frondosa, L. edodes, P. pulmonarius and P. ostreatus may be recommended in nutriceutical and pharmaceutical industries to develop biotech products with HGE and HTE. 3,11,12,21,22 The inhibition of ACE is considered the main mechanism of HTE of mushrooms. ${ }^{39}$

The well-known fibrinolytic agents, such as tissue-type, urokinase-type, nattokinase and streptokinase, possess a wide range of clinical applications. However, their uncontrolled usage is costly and results in a number of side effects, including internal haemorrhage, allergic reactions, and limitation in specificity towards fibrin. ${ }^{44}$ Therefore, the search for natural sources of fibrinolytic agents is in demand. The Agaricomycetes mushrooms, belonging to different taxonomic and ecological groups, are considered active producers of extracellular proteolytic (fibrinolytic, thrombolytic and caseinolytic) enzymes. ${ }^{24-26,45-50}$ Previous systematic studies have revealed the presence of fibrinolytic and thrombolytic proteases in Armillariella mellea, ${ }^{45}$ A. polytricha ${ }^{26}$ Coprinoid mushrooms, ${ }^{46,49}$ F. velutipes,${ }^{51}$ Fomitopsis pinicola,${ }^{48}$ G. lucidum ${ }^{52}$ H. erinaceus,${ }^{53}$ Pleurotus eryngii var. ferulae, ${ }^{54}$ and P. ostreatus. ${ }^{55}$

The research data provide evidence for the usage of mushrooms as a healthy food to decrease the risk of MS and CVD. ${ }^{4,29,31-33}$ Mushroom-rich diet regulates some risk factors associated with cardiac diseases, such as the levels of total low-density lipoprotein (LDL), high-density lipoprotein (HDL), total cholesterol, fasting triacylglycerol, homocysteine, $\mathrm{AH}$, as well as the oxidative and inflammatory damage of vessels. ${ }^{37-39}$ With this treatment approach of CVD, several agaricoid and polyporoid MM, such as Chaga (Inonotus obliquus), Lion's Mane (H. erinaceus), Oyster mushroom (P. ostreatus), Maitake (G. frondosa), Turkey tail [Coriolus (=Trametes) versicolor], Reishi $(G$. lucidum), Shiitake (L.edodes), and Agarikon (Laricifomes officinalis) are considered potential natural products to develop myco-pharmaceuticals with CPE.4,8,19,23,39,53,56-59 Among these species, $G$. frondosa, G. lucidum, L. edodes, P. ostreatus, and P. pulmonarius are considered ideal products with low-calorie healthy diet to prevent the development of CVD due to high contents of fibres, proteins, and microelements. ${ }^{31-33}$ In particular, Pleurotus species decrease the levels of LDL and HDL, homocysteine, total cholesterol, and fasting triglycerides, prevent the development of $\mathrm{AH}$, diabetes, and other pathological conditions, as well as reduce oxidative stress. ${ }^{3,439}$ A pronounced HCE of $P$. ostreatus combined with inhibition of lipid peroxidation has been shown to reduce the incidence and size of atherosclerotic plaques in animals. ${ }^{59}$ Furthermore, lovastatin, the leading compound of statins (HMG-CoA reductase inhibitors), has been detected in this fungus. ${ }^{60}$ The usage of Pleurotus 
cornucopiae, A. auricula, A. polytricha, F. velutipes, and A. bisporus in the hypocholesterolemic, anti-atherosclerotic, anti-coagulant and anti-aggregant diet has been previously reported. ${ }^{31-33,59,61}$ The triterpenes, derived from G. lucidum, have been shown to inhibit the biosynthesis of cholesterol and protect against atherosclerosis by inhibition of ACE and platelet aggregation. ${ }^{7,9}$ The dried fruiting bodies of $A$. aegerita can significantly reduce the levels of total cholesterol, triacylglycerides and the atherogenic index in rats and have shown HCE and AOA. ${ }^{62}$ Therefore, they have a potential to be used in biomedicine as natural sources of phenolic antioxidants and hypocholesterolemic agents. The steroid ergosta-4-6-8(14),22-tetraen-3-one, isolated from Chinese medicinal mushroom Polyporus sclerotium, has been shown to possess aldosterone-antagonist effects with diuretic properties ${ }^{63}$ which could also be of benefit in CVD.

Thus, mushrooms are considered a promising source of naturally-derived cardioprotective biomolecules. Further studies of their CPE for biotechnological and biomedical usages are warranted.

\section{BIOLOGICAL RESOURCES OF MUSHROOMS WITH CARDIOPROTECTIVE EFFECT DISTRIBUTED IN ARMENIA}

The analysis of literature and own data to assess cardioprotective potential of agaricomycetous mushrooms in Armenia revealed 16 edible and 15 non-edible species of agaricoid, coprinoid, polyporoid and hymenochaetoid mushrooms, including A. bisporus, A. auricula-judae, Armillariella mellea, Coprinus comatus, Fomitopsis pinicola, Ganoderma lucidum, Hypholoma fasciculare, $P$. ostreatus, and Trametes versicolor have been reported in all floristic regions of Armenia (Table 1). Previously, several therapeutic effects, including hypolipidemic, hypoglycemic, antioxidant, antiinflammatory, anti-hypertensive, anti-obesity, hypotensive, and thrombolytic/fibrinolytic, have been revealed in these fungi. ${ }^{46-49,64-68}$ (Table 1).

Two wild-growing and cultivated edible mushrooms, $P$. ostreatus and A. bisporus, widely cultivated in Armenia, have been shown to possess AOA, HGE, HCE, THE and prevent the development of atherosclerosis. ${ }^{69}$ Traditionally, A. bisporus has been used in the treatment of CVD and stroke due to its anti-diabetic and anti-aging properties. ${ }^{41}$ (Table 1). The polysaccharides isolated from $P$. ostreatus and A. bisporus, as well as from A. auricula growing in Ijevan floristic region, showed antioxidant, hypolipidemic, antidiabetic and anticoagulant properties and may protect the heart from ischemia/reperfusion injury. ${ }^{43}$ The polysaccharides derived from A. auricula are considered natural antioxidants that safeguard myocardial function by maintaining the redox levels in the cardiac muscle, improve the left ventricular ejection fraction (LVEF) and shot axis fractional shortening parameters of the left ventricle in experimental models. ${ }^{43}$ 
The cultural liquid (CL) of eight polypores (Fomes fomentarius, Fomitella fraxinea, Fomitopsis pinicola, Laetiporus sulphureus, Trametes gibbosa, T. hirsuta, T. ochracea, and T. versicolor) has recently been screened for thrombolytic activity (TLA) on samples of thrombi obtained from human blood. ${ }^{47,48}$ The highest activity was detected in $F$. fraxinea (up to $100 \%$ ), followed by $F$. pinicola (up to $85 \%$ ), F. fomentarius (up to $83 \%$ ), and $L$. sulphureus (up to $69 \%$ ) strains, whereas the activity was weaker (20-55\%) in Trametes species. The screening of fibrinolytic activity (FLA) of CL samples of two agaricoid (F. velutipes, P. ostreatus) and two polyporoid (F. pinicola, G. lucidum) mushrooms revealed the highest activity in F. pinicola (95\%), followed by G. lucidum (55\%), P. ostreatus (54.0), and $F$. velutipes (51\%) (Badalyan et al. unpublished data). Thus, these findings show that mushrooms may be considered alternative natural sources of extracellular proteases to develop novel mycopharmaceuticals with TLA and FLA.

The milk-coagulating activity was detected in CL samples of $F$. pinicola and several coprinoid mushrooms. ${ }^{48,49}$ (Table 1). The hymenochaetoid fungi, Inonotus dryadeus, I. hispidus, I. obliquus, Phellinus gilvus, Ph. igniarius, Ph. pini, Ph. ribis, Ph. robustus, and Ph. torulosus growing in Armenia possess AOA, whereas HGE and HCE were mainly detected in Phellinus species (Ph. igniarius, Ph. linteus, Ph. pini, Ph. ribis). ${ }^{68}$ The HGE, FLA and CPE were reported in Coprinus comatus, Coprinellus micaceus, ${ }^{46,49}$ Volvariella volvacea ${ }^{70}$ Coriolus versicolor ${ }^{71}$ and Lentinus tigrinus ${ }^{72}$ widely distributed in Armenia (Table 1). C. versicolor is known for its hypoglycemic effect, however the effect of this species on myocardial function of patients with diabetic cardiomyopathy (DCM) remains unclear. The results of a recent study have shown a significant improvement of cardiac dysfunction after fungal extract treatment which decreased the extent of cardiac fibrosis in rats. ${ }^{71}$ This protective effect of $C$. versicolor in patients with DCM is associated with the suppression of TGF$\beta 1 /$ Smad signaling (transforming growth factor $\beta-1$ ) and attenuation of nucleotide-binding oligomerization domain (NOD)-like receptor protein 3 (NLRP3) activation, suggesting that fungal extract may be a therapeutic agent for treatment of diabetic mice. ${ }^{71}$

Thus, Agaricomycetes MM distributed in Armenia may be considered as a potential source of cardioprotective biomolecules to develop functional food and myco-pharmaceuticals for the prevention and treatment of CVD.

\section{CONCLUSION AND FUTURE PERSPECTIVES}

It is known that Agaricomycetes mushrooms can be considered as a functional food and remedies, due to their nutritional value, bioactive compounds and enzymes, for the prevention and treatment of several diseases, including MS and CVD. 
The current review discusses the resource value and potential CPE (hypolipidemic, hypoglycemic, antioxidant, anti-inflammatory, anti-hypertensive, anti-obesity, hypotensive, thrombolytic/fibrinolytic) of 31 species of edible and non-edible Agaricomycetes MM (e.g. A. bisporus, A. auricula-judae, C. comatus, G. lucidum, H. erinaceus and P. ostreatus) distributed in all floristic regions of Armenia.

Future myco-pharmacological and clinical studies are needed to elucidate the mechanisms of cardioprotective properties of responsible bioactive compounds. The biotechnological cultivation of selected species/strains will assist in the development of cardioprotective mushroom-derived biotech products and their biomedical application in Armenia.

\section{ACKNOWLEDGMENTS}

This research was supported by the SCS RA Thematic Project \#18T-1F115.

\section{REFERENCES}

1. De Mello WC, Danser AHJ. Angiotensin II and the heart: on the intracrine renin-angiotensin system. Hypertension. 2000; 35(6):1183-8.

2. Previtali E, Bucciarelli P, Passamonti SM, Martinelli I. Risk factors for venous and arterial thrombosis. Blood Transfus. 2011;9(2):120-38.

3. Badalyan SM. Medicinal aspects of edible ectomycorrhizal mushrooms. In: Zambonelli A, Bonito G, editors. Edible Ectomycorrhizal Mushrooms, Current Knowledge and Future Prospects. Vol 34. Heidelberg: Springer, 2012. p. 317-34.

4. Badalyan SM, Barkhudaryan A, Rapior S. Recent progress in research on the pharmacological potential of mushrooms and prospects for their clinical application. In: Agrawal D, Dhanasekaran M, editors. Medicinal Mushrooms - Recent Progress in Research and Development. Singapore: Springer Nature, 2019, p. 1-70.

5. Wu F, Zhou LW, Yang ZL, Bau T, Li TH, Dai YC. Resource diversity of Chinese macrofungi: edible, medicinal and poisonous species. Fungal Diversity. 2019;98:1-76.

6. Chen B, Tian J, Zhang J, Wang K, Liu L, Yang B, Bao L, Liu H. Triterpenes and meroterpenes from Ganoderma lucidum with inhibitory activity against HMGs reductase, aldose reductase and $\alpha$-glucosidase. Fitoterapia. 2017;120:6-16.

7. Kim HW, Kim BK. Biomedicinal triterpenoids of Ganoderma lucidum (Curt. : Fr.) P. Karst. (Aphyllophoromycetideae). Int J Med Mushrooms. 1999;1(2):121-38. 
8. Sturm S, Gallmetzer K, Friedl A, Waltenberger B, Temml V, Stuppner H. Laricifomes officinalis - a rich source of pharmacologically active triterpenes. Planta Med. 2016;81:S1S381.

9. Morigiwa A, Kitabatake K, Fujimoto Y, Ikekawa N. Angiotensin converting enzymeinhibitory triterpenes from Ganoderma lucidum. Chem Pharm Bull. 1986;34:3025-28.

10. Afrin S, Rakib MA, Kim BH, Kim JO, Ha YL. Eritadenine from edible mushrooms inhibits activity of angiotensin converting enzyme in vitro. J Agric Food Chem. 2016;64(11):226368.

11. Ferreira IC, Barros L, Abreu RM. Antioxidants in wild mushrooms. Curr Med Chem. 2009;16:1543-60.

12. Witkowska AM, Zujko ME, Mironczuk-Chodakowska I. Comparative study of wild edible mushrooms as sources of antioxidants. Int J Med Mushrooms. 2011;13:335-41.

13. Saltarelli R, Ceccaroli P, Buffalini M, Vallorani L, Casadei L, Zambonelli A, Iotti M, Badalyan S, Stocchi V. Biochemical characterization, antioxidant and antiproliferative activities of different Ganoderma collections. J Mol Microbiol Biotechnol. 2015;25(1):16-25.

14. Morel S, Arnould S, Vitou M, Boudard F, Guzman C, Poucheret P, Fons F, Rapior S. Antiproliferative and antioxidant activities of wild Boletales mushrooms from France. Int $\mathbf{J}$ Med Mushrooms. 2018,20(1):13-29.

15. De Silva DD, Rapior S, Hyde KD, Bahkali AH. Medicinal mushrooms in prevention and control of diabetes mellitus. Fungal Diversity. 2012;56:1-29.

16. Ma HT, Hsieh JF, Chen ST. Anti-diabetic effects of Ganoderma lucidum. Phytochem. 2015;114:109-113.

17. Yamac M, Kanbak G, Zeytinoglu M, Zeytİnoglu M, Senturk H, Bayramoglu G, Dokumacíoglu A, Van Griensven LJLD. Pancreas protective effect of button mushroom Agaricus bisporus (J.E. Lange) Imbach (Agaricomycetidae) extract on rats with Streptozotocin-induced diabetes. Int J Med Mushrooms. 2010; 12(4):379-89.

18. Yamac M, Zeytinoglu M, Swenturk H, Kartkaya K, Kanbak G, Bayramoglu G, Oglakci A, Van Griensven LJLD. Effects of black hoof medicinal mushroom, Phellinus linteus (Agaricomycetes), polysaccharide extract in streptozotocin-induced diabetic rats. Int J Med Mushrooms. 2016;18(4):301-11.

19. Thongbai B, Rapior S, Hyde KD, Wittstein K, Stadler M. Hericium erinaceus, an amazing medicinal mushroom. Mycol Progress. 2015;14:91.

20. Abidin MHZ, Abdullah N, Abidin NZ. Anti-atherogenic potential of extracts from the gray oyster medicinal mushroom, Pleurotus pulmonarius (Agaricomycetes), in vitro. Int J Med Mushrooms. 2018;20(3):283-90. 
21. Gil-Ramirez A, Morales D, Soler-Rivas C. Molecular actions of hypocholesterolaemic compounds from edible mushrooms. Food Funct. 2017;9(1):53-69.

22. Kabir Y, Yamaguchi M, Kimura S. Effect of shiitake (Lentinus edodes) and Maitake (Grifola frondosa) mushrooms on blood pressure and plasma lipids of spontaneously hypertensive rats. J Nutr Sci Vitaminol. 1987;33:341-6.

23. Chien RC, Lin LM, Chang YH, Lin YC, Wu PH, Asatiani MD, Wasser SG, Krakhmalnyi M, Agbarya A, Wasser SP, Mau JL. Anti-inflammation properties of fruiting bodies and submerged cultured mycelia of culinary-medicinal higher Basidiomycetes mushrooms. Int J Med Mushrooms. 2016;18(11):999-1009.

24. Kudryavtseva OA, Dunaevsky YE, Kamzolkina OV, Belozersky MA. Fungal proteolytic enzymes: features of the extracellular proteases of xylotrophic Basidiomycetes. Microbiology. 2008;77(6):643-53.

25. Denisova NP. History of the study of thrombolytic and fibrinolytic enzymes of higher basidiomycetes mushrooms at the VL Komarov Botanical Institute in St Petersburg, Russia. Int J Med Mushrooms. 2010;12(3):317-25.

26. Ali SM, Tan YS, Raman J, Lakshmanan H, Ling TC, Phan CW, Sabaratnam W. Do culinary mushrooms have fibrinolytic activities? Biomed Rev. 2017;28:95-103.

27. Mattila P, Könkö K, Eurola M, Pihlava JM, Astola J, Vahteristo L, Hietaniemi V, Kumpulainen J, Valtonen M, Piironen V. Contents of vitamins, mineral elements, sand some phenolic compounds in cultivated mushrooms. J Agric Food Chem. 2001;49:2343-8.

28. Barros L, Venturini BA, Baptista P, Estevinho LM, Ferreira IC. Chemical composition and biological properties of Portuguese wild mushrooms: a comprehensive study. J Agric Food Chem. 2008;56:3856-62.

29. Kalač P. A review of chemical composition and nutritional value of wild-growing and cultivated mushrooms. J Sci Food Agric. 2013;93:209-18.

30. Badalyan SM. Fatty acid composition of different collections of coprinoid mushrooms (Agaricomycetes) and their nutritional and medicinal values. Int J Med Mushrooms. 2016;8(10):883-93.

31. Cheung PCK (editor). Mushrooms as functional foods. Hoboken, New Jersey: Wiley, 2008.

32. Cheung PCK. Mini-review on edible mushrooms as source of dietary fiber: preparation and health benefits. Food Sci Human Wellness. 2013;2:162-6.

33. Khatun S, Islam A, Cakilcioglu U, Chatterjee NC. Research on mushroom as a potential source of nutraceuticals: A Review on Indian perspective. American J Exp Agriculture. 2012;2(1): 47-73. 
34. VanderMolen KM, Litlle JG, Sica VP, El-Elimat T, Raja HA, Oberlies NH, Baker TR, Mahony C. Safety assessment of mushrooms in dietary supplements by combining analytical data with in silico toxicology evaluation. Food Chem Toxicol. 2017;103:133-47.

35. Chang ST, Wasser SP. Current and future research trends in agricultural and biomedical applications of medicinal mushrooms and mushroom products (Review). Int J Med Mushrooms. 2018;20(12): 1121-33.

36. Badalyan SM, Zambonelli A. Biotechnological exploitation of macrofungi for the production of food, pharmaceuticals and cosmeceuticals. In: Sridhar KR, Deshmukh SK, editors. Advances in Macrofungi: Diversity, Ecology and Biotechnology. Boca Raton: CRC Press, 2019, p. 199-230.

37. Guillamón E, García-Lafuente A, Lozano M, D'Arrigo M, Rostagno MA, Villares A, Martínez JA. Edible mushrooms: role in the prevention of cardiovascular diseases. Fitoterapia. 2010;81(7):715-23.

38. Choi E, Ham O, Lee SY, Song BW, Cha MJ, Lee CY, Park JH, Lee J, Song H, Hwang KC. Mushrooms and cardiovascular disease. Curr Topics Nutraceut Res. 2012;10(1):43-52.

39. Shibu MA, Agrawal DC, Huang CY. Mushrooms: a Pandora box of cardioprotective phytochemicals. In: Agrawal DC, Tsay HS, Shyur LF, Wu YC, Wang SY, editors. Medicinal and Aromatic Plants of the World. Vol 4. Medicinal Plants and Fungi: Recent Advances in Research and Development, Singapore: Springer Nature, 2017, p. 337-62.

40. Morales D, Piris AJ, Ruiz-Rodriguez A, Prodanov M, Soler-Rivas C. Extraction of bioactive compounds against cardiovascular diseases from Lentinula edodes using a sequential extraction method. Biotechnol Progress. 2018;34:746.

41. Bhushan A. Kulshreshtha M. Cardioprotective activity of Agaricus bisporus against isoproterenol-induced myocardial infarction in laboratory animals. Curr Nutrit Food Sci. 2019;15(4):401-7.

42. Su HH, Chu YC, Liao JM, Wang YH, Jan MS, Lin CW, Wu CY, Tseng CY, Yen JC, Huang SS. Phellinus linteus mycelium alleviates myocardial ischemia-reperfusion injury through autophagic regulation. Front Pharmacol. 2017;8:175.

43. Wu Q, Tan Z, Liu H, Gao L, Wu S, Luo J, Zhang W, Zhao T, Yu J, Xu X. Chemical characterization of Auricularia auricula polysaccharides and its pharmacological effect on heart antioxidant enzyme activities and left ventricular function in aged mice. Int J Biol Macromol. 2010;46:284-8.

44. Blann AD, Landray MJ, Lip GYH. ABC of antithrombotic therapy: An overview of antithrombotic therapy. BMJ Clinical Research. 2002;325(7367):762-5. 
45. Kim JH, Kim YS. A fibrinolytic metalloprotease from the fruiting bodies of an edible mushroom, Armillariella mellea. Biosci Biotechnol Biochem. 1999;63(12):2130-6.

46. Badalyan SM, Melikyan LR, Navarro-González M, Kües U. Fibrinolytic activity of several coprinoid mushrooms. In: The 6th International Conference on Mushroom Biology and Mushroom Products; 2008 Sep 29-Oct 3; Bonn, Germany. p. 66-7.

47. Badalyan SM, Gharibyan NG. Proteolytic and milk-coagulating activities of mycelia of several polypore mushrooms. In: Dyakov YT, editor. Current Mycology in Russia. Proceed. IIIrd Int. Mycological Forum. Vol 5. 2015 April 14-15; Moscow, Russia. p. 275-7.

48. Badalyan SM, Gharibyan NG, Shahbazyan TA, Shnyreva AV. Milk coagulating and thrombolytic activity of red-belt conk Fomitopsis pinicola. In: Sergeev YV, editor. Advances in Medical Mycology. Proceedings of Memorial Conference of Medical Mycology. Vol 16. 2016 April 14-15. Moscow, Russia. p. 239-42.

49. Badalyan SM. Medicinal coprinoid mushrooms (Agaricomycetes) distributed in Armenia (Review). Int J Med Mushrooms. 2020;22(3):257-67.

50. Lu LC, Chen SN. Fibrinolytic enzymes from medicinal mushrooms. In: Faraggi E. (editor). Biochemistry, Genetics and Molecular Biology. Protein Structure. InTech Open. 2012, p. 337-62.

51. Morozova EN, Falina NN, Denisova NP, Barkova LV, Psurtseva NV. Analysis of the component constitution and substrate specificity of a fibrinolytic preparation from the fungus Flammulina velutipes. Biokhimia. 1982;47(7):1181-5.

52. Kumaran S, Palani P, Nishanthi R, Kaviyarasan V. Studies on screening, isolation and purification of a fibrinolytic protease from an isolate (VK12) of Ganoderma lucidum and evaluation of its antithrombotic activity. Med Mycol J. 2011;52(2):153-62.

53. Choi BS, Sapkota K, Choi JH, Shin CH, Kim S, Kim SJ. Herinase: a novel bi-functional fibrinolytic protease from the monkey head mushroom, Hericium erinaceum. Appl Biochem Biotechnol. 2013;170(3):609-22.

54. Choi JH, Kim DW, Kim S, Kim SJ. Purification and partial characterization of a fibrinolytic enzyme from the fruiting body of the medicinal and edible mushroom Pleurotus ferulae. Prep Biochem Biotechnol. 2017;7(6):539-46.

55. Choi HS, Shin HH. Purification and partial characterization of a fibrinolytic protease in Pleurotus ostreatus. Mycologia. 1998;90(4):674-9.

56. Khatun K, Mahtab H, Khanam PA, Sayeed MA, Khan KA. Oyster mushroom reduced blood glucose and cholesterol in diabetic subjects. Mymensingh Med J. 2007;16:94-9. 
57. Wang C, Chen Z, Pan Y, Gao X, Chen H. Anti-diabetic effects of Inonotus obliquus polysaccharides-chromium (III) complex in type 2 diabetic mice and its sub-acute toxicity evaluation in normal mice. Food Chem Toxicol. 2017;108(Pt B):498-509.

58. Calvo MS, Mehrotra A, Beelman RB, Nadkarni G, Wang L, Cai W, Goh BC, Kalaras MD, Uribarri J. A retrospective study in adults with metabolic syndrome: diabetic risk factor response to daily consumption of Agaricus bisporus (white button mushrooms). Plant Foods Hum Nutr. 2016;71:245-51.

59. Bobek P. Galbavý Š. Hypocholesterolemic and anti-atherogenic effect of oyster mushroom (Pleurotus ostreatus) in rabbits. Mol Nutr Food Res. 1999;43(3):339-42.

60. Gunde-Cimmerman N. Medicinal value of the genus Pleurotus (Fr.) P. Karst. (Agaricales s.l., Basidiomycetes). Int J Med Mushrooms. 1999;1:69-80.

61. Chen G, Luo YC, Li BP, Li B, Guo Y, Li Y, Su W, Xiao ZL. Effect of polysaccharide from Auricularia auricula on blood lipid metabolism and lipoprotein lipase activity of ICR mice fed a cholesterol-enriched diet. J Food Sci. 2008; 73:H103-8.

62. Ng YF. In vitro and in vivo antioxidant activity and hypocholesterolemic effect in extracts of Agrocybe aegerita. Master of Philosophy Thesis. Hong Kong: The Chinese University of Hong Kong, 2005.

63. Yuan D, Mori J, Komatsu K, Makino T, Kano Y. An anti-aldosteronic diuretic component (drain dampness) in Polyporus sclerotium. Biol Pharm Bull. 2004;27:867-70.

64. Badalian SM, Serrano JJ. Hypoglycemic activity of the medicinal mushroom Hypholoma fasciculare (Fr.) Kumm. Int J Med Mushrooms. 1999;1(3):245-50.

65. Chen L, Zhang Y, Sha O, Xu W, Wang S. Hypolipidaemic and hypoglycaemic activities of polysaccharide from Pleurotus eryngii in Kunming mice. Int J Biol Macromol. 2016;93:12069.

66. Badalyan SM, Gharibyan NG. Diversity of polypore bracket mushrooms, Polyporales (Agaricomycetes) recorded in Armenia and their medicinal properties. Int J Med Mushrooms. 2016;1 (4):347-54.

67. Badalyan SM, Gharibyan NG. Characteristics of mycelial structures of different fungal collections. Yerevan: YSU Press; 2017.

68. Badalyan SM, Gharibyan NG. Biodiversity, resource value and medicinal properties of Hymenochaetales (Agaricomycetes) bracket fungi distributed in Armenia. A review. Int $\mathbf{J}$ Med Mushrooms. 2020;22(11).

69. Zhang Y, Wang Z, Jin G, Yang X, Zhou H. Regulating dyslipidemia effect of polysaccharides from Pleurotus ostreatus on fat-emulsion-induced hyperlipidemia rats. Int J Biol Macromol. 2017;101:107-16. 
70. Punitha SC, Rajasekaran M. Cardioprotective effect of Volvariella volvacea in streptozotocin administered rats. Bangladesh J Pharmacol. 2016;11(4):903-10.

71. Wang Y, Li H, Li Y, Zhao Y, Xiong F, Liu Y, Xue H, Yang Z, Ni S, Sahil A, Che H, Wang

L. Coriolus versicolor alleviates diabetic cardiomyopathy by inhibiting cardiac fibrosis and NLRP3 inflammasome activation. Phytother Res. 2019;33:2737-48.

72. Dulay RM, Arenas MC, Kalaw SP, Reyes RG, Cabrera EC. Proximate composition and functionality of the culinary-medicinal tiger sawgill mushroom, Lentinus tigrinus (higher Basidiomycetes), from the Philippines. Int J Med Mushrooms. 2014;16(1):85-94. 
Table 1: Taxonomy, bioactive compounds and medicinal (cardioprotective) effects of medicinal Agaricomycetes mushrooms growing in Armenia 


\begin{tabular}{|c|c|c|c|c|c|}
\hline $\mathrm{N}$ & Mushrooms species & Floristic regions & Bioactive compounds & Medicinal effects & References \\
\hline 1. & $\begin{array}{l}\text { *Agaricus bisporus (J.E. Lange) } \\
\text { Imbach }\end{array}$ & GG,YE & $\begin{array}{l}\text { Polysaccharides, } \\
\text { ergothioneine, polyphenols, } \\
\text { vitamins }\end{array}$ & $\begin{array}{l}\text { Antioxidant, anti-inflammatory, } \\
\text { hypoglycemic, pancreas protective, } \\
\text { hypocholesterolemic, hypotensive, } \\
\text { cardioprotective }\end{array}$ & $5,17,42,58$ \\
\hline 2. & $\begin{array}{l}\text { *Agrocybe }(=\text { Cyclocybe }) \text { aegerita }(\mathrm{V} . \\
\text { Brig.) Vizzini }\end{array}$ & YE & Polysaccharides, phenolics & $\begin{array}{l}\text { Antioxidant, anti-atherosclerotic, } \\
\text { hypoglycemic }\end{array}$ & $62,37,39$ \\
\hline 3. & *Armillariella mellea (Vahl) P. Kumm. & YE,AP,IJ,LR,SE,ZG & Polysaccharides, proteases & Fibrinolytic, hypotensive, spasmolytic & 5,45 \\
\hline 4. & $\begin{array}{l}\text { *Auricularia auricula-judae (Bull.) J. } \\
\text { Schröt. }\end{array}$ & IJ & Polysaccharides, phenolics & $\begin{array}{l}\text { Antioxidant, anti-coagulant, } \\
\text { cardiovascular, hypolipidemic, } \\
\text { hypoglycemic, fibrinolytic }\end{array}$ & $4,5,39,61,67$ \\
\hline 5. & *Boletus edulis Bull. & AP,IJ,LR,ZG & $\begin{array}{l}\text { Polysaccharides, } \\
\text { oligopeptides, polyphenols, } \\
\text { vitamins }\end{array}$ & $\begin{array}{l}\text { Antioxidant, anti-inflammatory, anti- } \\
\text { atherosclerotic, ACE-inhibitory }\end{array}$ & $3,36,37,39$ \\
\hline 6. & *Cantharellus cibarius Fr. & IJ,LR & Polysaccharides, phenolics & $\begin{array}{l}\text { Antioxidant, anti-inflammatory, } \\
\text { cardioprotective, hypolipidemic, } \\
\text { hypoglycemic }\end{array}$ & 3,5 \\
\hline 7. & *Coprinus comatus (O.F. Müll.) Pers. & YE,IJ,LR,SV,ZG & $\begin{array}{l}\text { Polysaccharides, } \\
\text { tocopherols, phenolics, fatty } \\
\text { acids, proteases }\end{array}$ & $\begin{array}{l}\text { Anti-inflammatory, anti-obesity, } \\
\text { antioxidant, cardiovascular, } \\
\text { hypoglycemic, fibrinolytic, } \\
\text { thrombolytic }\end{array}$ & $5,46,49$ \\
\hline 8. & $\begin{array}{l}\text { Coprinellus micaceus (Bull.) Vilgalys, } \\
\text { Hopple \& Jacq. Johnson }\end{array}$ & YE,IJ,LR & $\begin{array}{l}\text { Polysaccharides, fatty acids, } \\
\text { proteases }\end{array}$ & Hypoglycemic, thrombolytic & $5,46,49$, \\
\hline 9. & $\begin{array}{l}\text { Coprinopsis strossmayeri (Schulzer) } \\
\text { Redhead, Vilgalys \& Moncalvo }\end{array}$ & YE & $\begin{array}{l}\text { Terpenoids, linoleic, } \\
\text { palmitic, stearic, oleic acids }\end{array}$ & Antioxidant, caseinolytic, fibrinolytic & $5,46,49$ \\
\hline 10. & *Flammulina velutipes (Curtis) Singer & YE,IJ,LR,AP & $\begin{array}{l}\text { Polysaccharides, fatty acids, } \\
\text { steroids, tocopherols, } \\
\text { proteases }\end{array}$ & $\begin{array}{l}\text { Antioxidant, anti-atherosclerotic, anti- } \\
\text { inflammatory, hypocholesterolemic, } \\
\text { hypotensive, fibrinolytic, thrombolytic }\end{array}$ & $4,37,39,51$ \\
\hline 11. & Fomes fomentarius (L.) Fr. & All & $\begin{array}{l}\text { Phenolics, flavonoids, } \\
\text { exopolysaccharides, } \\
\text { triterpenoids, ketones, } \\
\text { proteases }\end{array}$ & $\begin{array}{l}\text { Antioxidant, anti-inflammatory, } \\
\text { hypoglycemic, hypolipidemic, } \\
\text { fibrinolytic, thrombolytic }\end{array}$ & $4,47,48,67$ \\
\hline 12. & Fomitopsis pinicola (Sw.) P. Karst. & LR,ZG & $\begin{array}{l}\text { Polysaccharides, sterols, } \\
\text { triterpenoids, flavonoids, } \\
\text { proteases }\end{array}$ & $\begin{array}{l}\text { Anti-inflammatory, antioxidant, anti- } \\
\text { obesity, anti-atherosclerosis, } \\
\text { thrombolytic, fibrinolytic }\end{array}$ & $47,48,66,67$ \\
\hline
\end{tabular}




\begin{tabular}{|c|c|c|c|c|c|}
\hline 13. & Ganoderma lucidum (Curtis) P. Karst. & IJ,LR,SV,ZG & $\begin{array}{l}\text { Polysaccharides, lanostane } \\
\text { terpenoids, phenolics, fatty } \\
\text { acids, steroids, tocopherols }\end{array}$ & $\begin{array}{l}\text { Antioxidant, , anti-aggregation, anti- } \\
\text { inflammatory, anti-hypertensive, anti- } \\
\text { obesity hypoglycemic, } \\
\text { hypocholesterolemic, fibrinolytic, } \\
\text { thrombolytic, }\end{array}$ & $\begin{array}{l}4-7,9,16,36,37 \\
39,47,48,52,66\end{array}$ \\
\hline 14. & Ganoderma adspersum (Schulz.) Donk & YE,IJ & $\begin{array}{l}\text { Polysaccharides, terpenoids, } \\
\text { phenolics }\end{array}$ & $\begin{array}{l}\text { Antioxidant, antihypertensive, } \\
\text { hypoglycemic, hypocholesterolemic, } \\
\text { fibrinolytic }\end{array}$ & $5,47,48,67$ \\
\hline 15. & *Hericium erinaceus (Bull.) Pers. & $\mathrm{IJ}, \mathrm{ZG}$ & $\begin{array}{l}\text { Meroterpenoids, } \\
\text { erinacerins, } \\
\text { erinaceolactones, } \\
\text { hericenones, herinase }\end{array}$ & $\begin{array}{l}\text { Antioxidant, anti-inflammatory, anti- } \\
\text { obesity, hypoglycemic, } \\
\text { hypocholesterolemic, fibrinolytic }\end{array}$ & $4,5,19,53$ \\
\hline 16. & Hypholoma fasciculare (Fr.) Kumm. & AP,IJ,LR,YE,ZG & Proteases & Hypoglycemic, fibrinolytic, vasodilator & 4.64 \\
\hline 17. & Inonotus dryadeus (Pers.) Murrill & $\mathrm{IJ}, \mathrm{ZG}$ & $\begin{array}{l}\text { Free fatty acids, cerevisterol, } \\
\text { sphingosine }\end{array}$ & Antioxidant & 68 \\
\hline 18. & Inonotus hispidus (Bull.) P. Karst. & YE,IJ,LR,MG,ZG & $\begin{array}{l}\text { Phenolic compounds, } \\
\text { hispidin }\end{array}$ & $\begin{array}{l}\text { Antioxidant, anti-inflammatory, } \\
\text { antidiabetic, cardioprotective }\end{array}$ & 68 \\
\hline 19. & Inonotus obliquus(Ach. ex Pers.) Pilát & IJ,LR & $\begin{array}{l}\text { Phenolic compounds, } \\
\text { melanin, xylo-galactoglucan, } \\
\text { polysaccharides, flavonoids }\end{array}$ & $\begin{array}{l}\text { Anti-obesity, anti-diabetic, anti- } \\
\text { oxidant, anti-inflammatory, } \\
\text { cardioprotective }\end{array}$ & 5,68 \\
\hline 20. & *Laetiporus sulphureus (Bull.) Murrill & YE,IJ,LR,ZG & $\begin{array}{l}\text { Phenolics, polysaccharides, } \\
\text { proteases }\end{array}$ & Antioxidant, thrombolytic & $5,66,67$ \\
\hline 21. & *Lentinus tigrinus (Bull.) Fr. & YE,IJ,LR & $\begin{array}{l}\text { Phenolics, sterols, } \\
\text { polysaccharides, proteins }\end{array}$ & $\begin{array}{l}\text { Antioxidant, hypoglycemic, } \\
\text { hypocholesterolemic }\end{array}$ & $5,67,72$ \\
\hline 22. & Phellinus igniarius (L.) Quél. & All & $\begin{array}{l}\text { Phenolic acids, } \\
\text { polysaccharides, } \\
\text { hispidin }\end{array}$ & $\begin{array}{l}\text { Anti-inflammatory, antioxidant, anti- } \\
\text { diabetes }\end{array}$ & 68 \\
\hline 23. & $\begin{array}{l}\text { Phellinus pini (Brot.) Bondartsev \& } \\
\text { Sing. }\end{array}$ & IJ,LR & $\begin{array}{l}\text { Hispidin, squarrosidine, } \\
\text { free phenolic acids, } \\
\text { polysaccharides }\end{array}$ & $\begin{array}{l}\text { Antioxidant, hypoglycemic, } \\
\text { hypolipidemic }\end{array}$ & 68 \\
\hline 24. & Phellinus ribis (Schumach.) Quél. & IJ,MG,ZG & Glucan, hispidin & $\begin{array}{l}\text { Antioxidant, anti-inflammatory, anti- } \\
\text { diabetes }\end{array}$ & 6868 \\
\hline 25. & $\begin{array}{l}\text { *Pleurotus cornucopiae (Paulet) } \\
\text { Rolland }\end{array}$ & AP,YE,IJ,LR,ZG & $\begin{array}{l}\text { Phenolics, fatty acids, } \\
\text { mannogalactoglucans, } \\
\text { oligopeptides }\end{array}$ & $\begin{array}{l}\text { ACE inhibitory, Anti-inflammatory, } \\
\text { antioxidant, hypoglycemic, } \\
\text { hypocholesterolemic, hypotensive }\end{array}$ & $4,5,39,67$ \\
\hline
\end{tabular}




\begin{tabular}{|c|c|c|c|c|c|}
\hline 26. & *Pleurotus eryngii (DC.) Quél. & YE & $\begin{array}{l}\text { Phenolics, polysaccharides, } \\
\text { fatty acids, proteases }\end{array}$ & $\begin{array}{l}\text { Anti-inflammatory, antioxidant, } \\
\text { hypoglycemic, hypocholesterolemic, } \\
\text { hypotensive, fibrinolytic }\end{array}$ & $5,67,37,39,54,65$ \\
\hline 27. & *Pleurotus ostreatus (Jacq.) P. Kumm. & $\begin{array}{l}\mathrm{YE}, \mathrm{IJ}, \mathrm{LR} \\
\end{array}$ & $\begin{array}{l}\text { Protocatechuic acid, gallic } \\
\text { acids, lovastatin, } \\
\text { formononetin, } \\
\text { polysaccharides, fatty acids, } \\
\text { steroids, tocopherols, } \\
\text { vitamins, proteases }\end{array}$ & $\begin{array}{l}\text { Anti-inflammatory, anti-obesity, } \\
\text { antioxidant, anti-atherosclerotic, } \\
\text { anticoagulant against } \\
\text { ischemia/reperfusion injury, } \\
\text { cardioprotective, hypocholesterolemic, } \\
\text { hypoglycemic, hypotensive, } \\
\text { fibrinolytic, thrombolytic }\end{array}$ & $4,37,39,59,60,67,69$ \\
\hline 28. & *Pleurotus pulmonarius (Fr.) Quél. & YE,IJ & $\begin{array}{l}\text { Phenolics, polysaccharides, } \\
\text { fatty acids }\end{array}$ & $\begin{array}{l}\text { Anticoagulant, antidiabetic, } \\
\text { antioxidant, anti-atherogenic, anti- } \\
\text { inflammatory, hypocholesterolemic, } \\
\text { hypotensive }\end{array}$ & $4,5,20$ \\
\hline 29. & $\begin{array}{l}\text { Trametes }(=\text { Coriolus) versicolor }(\mathrm{L} .) \\
\text { Lloyd }\end{array}$ & $\mathrm{IJ}, \mathrm{LR}, \mathrm{YE}$ & $\begin{array}{l}\text { Polysaccharides, phenolics, } \\
\text { proteases }\end{array}$ & $\begin{array}{l}\text { Antioxidant, anti-obesity, anti-diabetic, } \\
\text { cardioprotective, thrombolytic }\end{array}$ & $4,5,39,66,67,71$ \\
\hline 30. & Trametes hirsuta (Wulfen) Pilát & YE & $\begin{array}{l}\text { Polysaccharides, phenolics, } \\
\text { proteases }\end{array}$ & Antioxidant, thrombolytic & 4 \\
\hline 31. & *Volvariella volvacea (Bull.) Singer & YE,IJ & $\begin{array}{l}\text { Phenolic compounds, } \\
\text { flavonoids, ascorbic acid, } \beta \text { - } \\
\text { carotene, lycopene }\end{array}$ & Antioxidant, hypotensive & $4,5,37,39,70$ \\
\hline
\end{tabular}

Supprimé:

(*) Edible mushroom species; Floristic regions of Armenia: (AG) - Aragats; (AP) - Aparan; (DG) - Daralegez; (GG) - Gegama; (IJ) - Ijevan; (LR) - Lori; (MG) - Meghri; (SH) Shirak; (SV) - Sevan; (UA) - Upper Akhuryan; (YE) - Yerevan; (ZG) - Zangezur 